\title{
The use of medication as a preemptive strategy in teething children in a Nigerian community
}

\section{O. I. Opeodu, O. O. Denloye ${ }^{1}$}

Department of Periodontology and Community Dentistry, ${ }^{1}$ Department of Child Oral Health, College of Medicine, University of Ibadan, Oyo, Nigeria

\author{
Address for correspondence: \\ Dr. O. I. Opeodu, \\ Department of Periodontology \\ and Community Dentistry, \\ College of Medicine, University of \\ Ibadan, Oyo, Nigeria. \\ E-mail: opeodulanre1971@gmail.com
}

\begin{abstract}
Context: Teething, which is the eruption of primary teeth in infancy, had been associated with various types of symptoms by both the parents and some healthcare workers. The association of symptoms with teething had led to the use of medications to alleviate these symptoms, which in some cases had claimed the lives of some of the children. Aims: This study aims at assessing the belief and practice of nursing mothers concerning the use of pre-emptive medications for children in order to prevent perceived symptoms of teething. Settings and Design: Cross-sectional study among nursing mothers who brought their children to immunization clinic. Subject and Methods: An interviewer-administered questionnaire was used to assess the belief of nursing mothers on the use of pre-emptive medications against perceived symptoms of teething, the drugs used and the age of their children when they started using the drug(s). Statistical Analysis: Data analysis was done using statistical package for social sciences (SPSS) version 14. Analysis included frequency, mean of quantitative values and cross tabulations. Chi-square test was used to assess the relationship between those mothers, who believed that the medication should be used and those who did not believe in relationship with their age and their socio-economic status. Results: A total of 290 nursing mothers were assessed with $169(58.3 \%)$ believing that drugs should be used as a pre-emptive measure for teething to be uneventful. Twenty-five (8.6\%) of the mothers started the medications soon after birth, whereas $34.5 \%$ started it after the third month of life. Conclusions: There is the need for greater public enlightenment in order to reduce the use of medication(s) as a pre-emptive measure against "teething" as seen among the studied group.
\end{abstract}

Ke y words

Children, medication, pre-emptive, teething

\section{INTRODUCTION}

Teething, defined as the eruption of primary teeth in infancy, ${ }^{[1]}$ has been associated with many symptoms that necessitated the use of various medications to remedy the situation. Hippocrates was said to have regarded teething as a cause of severe illness including fever, convulsion and diarrhea and teething was once tagged "Dentio difficilis" meaning difficult dentition. ${ }^{[2-4]}$ Therefore, many medicaments had been used in the management of symptoms perceived to be accompanying teething, some of this medicaments contain opiates,

\begin{tabular}{|l|l|}
\hline \multicolumn{2}{|c|}{ Access this article online } \\
\hline Quick Response Code: & Website: \\
\hline & www.ejgd.org \\
\cline { 2 - 3 } & \\
\hline
\end{tabular}

lead acetate, mercurial, bromide, paracetamol and diphenhydramine. Alternative therapy such as herbal products, talisman and other phylactery have also been used for the same purpose. ${ }^{[3,4]}$ Some have advocated the use of alcohol to numb the gums of a teething infant. ${ }^{[5]}$ Some of the parents only use this drug(s) to treat symptom(s) perceived to be due to teething, whereas others use it, pre-emptively, in anticipation of teething symptoms and thus usually start the drug before the commencement of teething process in their children. The use of some of the medicaments had been implicated as the cause of potentially fatal symptoms ${ }^{[6,7]}$ among children, while there had been reported cases of death of children following the ingestion of contaminated teething mixture used in the treatment and or preventing teething symptoms. ${ }^{[8,9]}$

The present study was therefore carried out to assess the belief and practice of nursing mothers concerning the use of medication in order to prevent symptoms that are perceived to be due to teething in their children. We believed that the 
findings of this study will contribute towards the eradication of such a practice that can actually be avoided.

\section{SUBJECTS AND METHODS}

A cross-sectional study of 290 nursing mothers attending the immunization clinics of two hospitals in Ibadan, Nigeria, for their children's immunization was carried out to assess their belief and practice concerning the use of pre-emptive medication in preventing the occurrence of symptoms perceived to be due to teething in their children. A 35-item questionnaire was administered on each of the nursing mothers to assess their practice concerning the use of medications in order to prevent teething symptoms, to know the type of the drugs used and when they actually started giving the drugs to their children. The data collected also included the age of the mothers, the gender of the child and the acquired source for the particular drug(s) used for their children. The women were classified into socio-economic status based on the classification by Famuyiwa et al., ${ }^{[10]}$ with some modifications.

Data analysis was done using statistical package for social sciences (SPSS) version 14. Analysis included frequency, mean of quantitative values and cross tabulations. Chi-square test was used to assess the relationship between those mothers who believed that the medication should be used and those who did not believe in relationship with their age and their socio-economic status. Level of statistical significance was set at $P<0.05$. Ethical approval was obtained from the local Institutional Review Committee before the commencement of the study.

\section{RESULTS}

The age of the mothers ranges from 20 to 45 years with the mean age being $29.4 \pm 4.9$ years. Seventy-four (25.5\%) of the women were in the age range 20-25 years, 112 (38.6\%) were between the age range 26-30 years, $68(23.5 \%)$ of them were in the age range of $31-35$ and $36(12.4 \%)$ of them were older than 36 years of age. Most of the respondents $(179 / 290)$ were unskilled labors, 60 (20.7\%) were civil servants, 34 (11.7\%) were the semi-skilled labors and $10(3.5 \%)$ of the women were students [Table 1]. Concerning the preferred source of information on teething by respondents, 140 (48.3\%) of them depended on their friends/family members, 101 (34.8\%) preferred consulting a medical practitioner, 31 (10.7\%) consulted patent medicine sellers and the remaining 18 (6.2\%) preferred a combination of books, medical practitioners and internet as source of information on teething.

When the views of the mothers were sought concerning the use of medication(s) for the symptomatic relief of symptom(s) perceived by the mothers to be due to teething, self-medication was the most common method by which the mothers sourced for the drugs that they used for their children as $63.4 \%$ of the mothers made use of over-the-counter (OTC) medication for this purpose. Eleven (3.8\%) of the mothers did not use any medication, either for symptomatic or preventive treatment, for teething in their children, while $29.7 \%$ preferred taking the child to the nearest hospital to seek medical advice in case of ill-health during teething [Table 2]. Teething mixture was the most used single medication by the respondents, as $43.5 \%$ utilized this drug whereas $31.0 \%$ made use of paracetamol and $1.7 \%$ made use of local herbs. Those respondents who used the drugs symptomatically to treat symptoms that they believed was due to teething discontinued the drug as soon as the symptoms resolved [Figure 1].

Those who did not use any medication with the mind set of preventing the onset of teething symptoms constituted $41.7 \%$ of all the respondents. Among those who used the drug(s) for preventive purpose, 8.6\% commenced the medication for their children soon after birth and $34.5 \%$ started the medication after 3 months of the child birth [Figure 2]. There was a statistically significant difference between the belief in the use of pre-emptive medication and the age group of the respondents $P<0.004$ [Table 3], whereas no statistical significant difference was found between the use of the medication and the socio-economic status of the respondents $P=0.063$.

\section{DISCUSSION}

Teething mixture was the most used of the various listed remedies for the treatment/prevention of symptoms that was believed to be due to teething, by the mothers in

\begin{tabular}{lc}
$\begin{array}{l}\text { Table 1: Distribution of respondents according to their } \\
\text { socio-economic status }\end{array}$ & Frequency (\%) \\
\hline Socioeconomic status & $7(2.4)$ \\
\hline Professionals & $60(20.7)$ \\
Civil Servants & $34(11.7)$ \\
Semi-skilled labor & $179(61.7)$ \\
Unskilled labor & $10(3.5)$ \\
Students* & $290(100)$ \\
\hline
\end{tabular}

*Indicates modification to original classification

\begin{tabular}{|c|c|c|}
\hline & Frequency & Percentage \\
\hline Self-medication & 184 & 63.4 \\
\hline Use herbal products & 5 & 1.7 \\
\hline Go to hospital & 86 & 29.7 \\
\hline None & 11 & 3.8 \\
\hline Combination & 4 & 1.4 \\
\hline Total & 290 & 100 \\
\hline
\end{tabular}




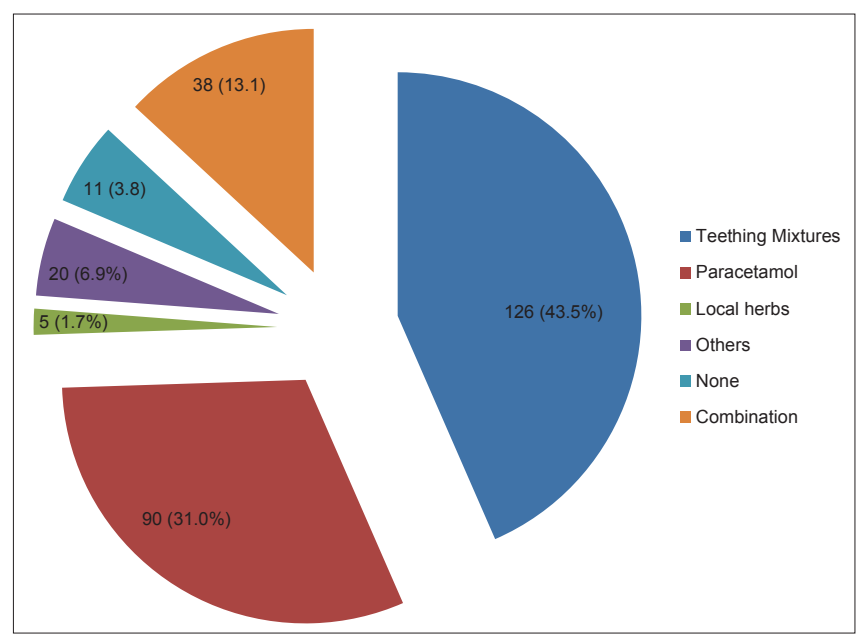

Figure 1: Types of drugs used by mothers for their teething children

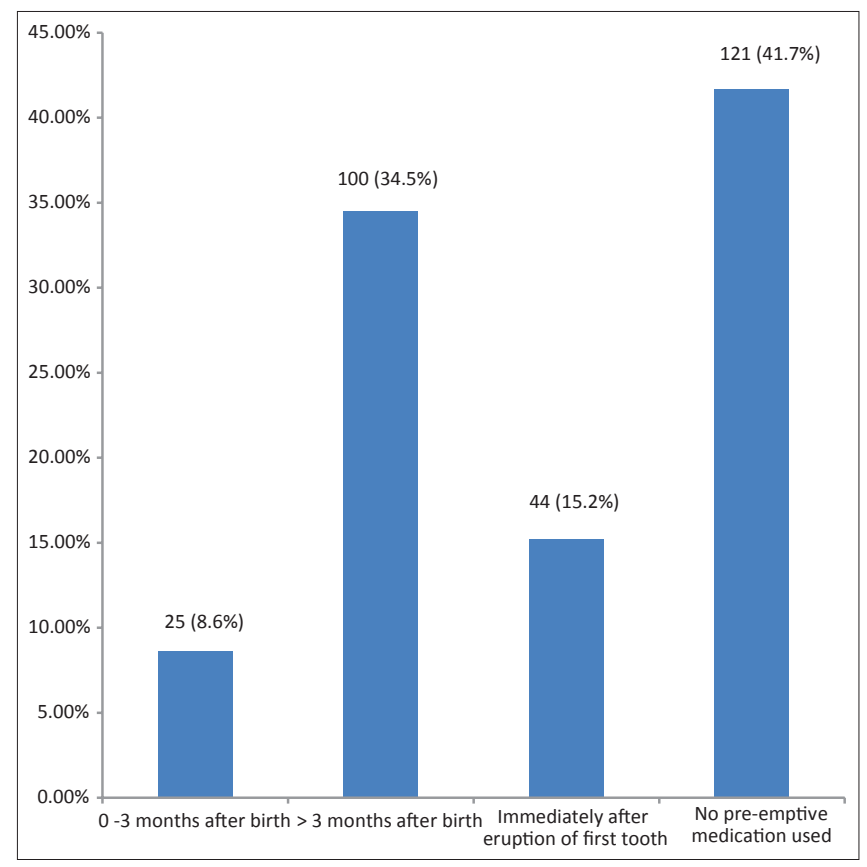

Figure 2: The age of child when pre-emptive medication was commenced

\begin{tabular}{|c|c|c|c|c|c|}
\hline \multicolumn{6}{|c|}{$\begin{array}{l}\text { Table 3: Comparison of the belief of the mothers } \\
\text { concerning the use of preventive medication for } \\
\text { teething with their age groups }\end{array}$} \\
\hline \multirow{2}{*}{$\begin{array}{l}\text { Use of preventive } \\
\text { medications }\end{array}$} & \multicolumn{4}{|c|}{ Age groups of mothers (\%) } & \multirow[t]{2}{*}{ Total } \\
\hline & 1 & 2 & 3 & 4 & \\
\hline Yes & $53(31.4)$ & $68(40.2)$ & $37(21.9)$ & $11(6.5)$ & 169 (100) \\
\hline No & $21(17.4)$ & $44(36.4)$ & $38(31.4)$ & $18(14.9)$ & $121(100)$ \\
\hline Total & $74(25 \cdot 5)$ & $112(38.6)$ & $75(25.9)$ & $29(10.0)$ & $290(100)$ \\
\hline
\end{tabular}

this study and most of them sourced for the drugs OTC, without any consultation. This shows that most of the mothers in the study do not bother to confirm whether or not the symptom(s) in their children is really due to teething or not. The danger in this type of behavior is that life threatening condition(s) may be overlooked and treated as "teething" with the mothers making use of self-medication and therefore, the tendency to present late to hospital with such a child. This becomes more important as serious symptoms such as diarrhea, vomiting and fever had been variously associated with teething by parents and some health workers. ${ }^{[11-13]}$ The practice of the use of preventive medications in anticipation of symptoms during teething is contrary to studies that have reported that teething seems not to be associated with symptoms and as such, should be treated as diagnosis of exclusion, in which case any child that is ill enough to be admitted in the hospital, should be screened for other possible organic cause of the illness, so that the child can be properly managed. ${ }^{[14,15]}$ This finding in this study also goes a long way in showing how easy it is to procure medication(s) OTC in the country without any formal consultation with a medical expert, which might not be the case in some other countries where greater restrictions are placed on access to drugs. ${ }^{[16]}$

Some of the mothers who did not use the medication on regular basis for the purpose of pre-empting teething symptoms actually made use of the medication for symptomatic treatment of teething symptoms, with majority of them doing so without formal medical consultation. There is need to exercise restraint as some of these medications contain benzocaine, which had been implicated as a possible cause of methaemoglobin, which is potentially fatal. ${ }^{[6,7]}$ This potential danger may be avoided if medical consultation is encouraged among mothers, as attending physician may be able to rule out the possibility of the danger with adequate history taking. The factors associated with the preference of the use of OTC to seeking medical advice by respondents in this study was not sought, but it might not have been unconnected with access to medical care or cost of treatment, which had been implicated as factors responsible for the use of folk remedies in the treatment of teething symptoms by people of low socio-economic status. ${ }^{[5]}$

There was a statistically significant relationship between ages of the mothers with their use of preventive teething medication, with more of the younger ones making use of the medication than the older ones [Table 3]. This possibly could have been a reflection of the sources of their information, which many (48.3\%) claimed was from their family/friends. This is comparable to the findings by Smitherman et al., 2005, who reported that tradition on handling of teething symptoms were handed down from one generation to another. ${ }^{[5]}$ The effect of personal experience gained by the older women with the raising of previous children could have accounted for their not making use of preventive teething remedies as much as the younger ones. There is therefore the need to assess the effects of previous child rearing on the way mothers handle teething in their children. 


\section{CONCLUSION}

There is the need for greater public enlightenment in order to reduce the use of medication(s) as a pre-emptive measure against "teething" as seen among the studied group.

\section{ACKNOWLEDGMENT}

We wish to acknowledge some doctors who helped in the collection of data for the study and the hospital authorities who granted us permission to collect the data.

\section{REFERENCES}

1. Baykan Z, Sahin F, Bayazova U, Özçakar B, Baykan A. Experience of Turkish parents about their infants' teething. Child Care Health Dev 2004;30:331-6.

2. Macknin ML, Piedmonte M, Jacobs J, Skibinski C. Symptoms associated with infant teething: A prospective study. Pediatrics 2000;105:747-52.

3. Ashley MP. It's only teething. A report of the myths and modern approaches to teething. Br Dent J 2001;191:4-8.

4. McIntyre GT, McIntyre GM. Teething troubles. Br Dent $\mathrm{J}$ 2002;192:251-5.

5. Smitherman LC, Janisse J, Mathur A. The use of folk remedies among children in an urban black community: Remedies for fever, colic, and teething. Paediatrics 2005;115:e297-304.

6. FDA warning. Benzocaine and babies: Not a good mix. Available from: http://www.fda.gov/forconsumers/consumerupdates/ucm306062. htm 1 of 3. [Last accessed on 2013 Mar 01].

7. AAFP News. Risk posed by popular teething Meds prompts FDA warning to parents, physicians. Family Doc offers alternatives to benzocaine products. Available from: http://www.aafp.org/online/ en/home/publications/news/news-now/heal. 1 of 4 . [Last accessed on 2013 Mar 01].

8. Howden D (2009). Tainted teething syrup kills 84 babies in Nigeria. News The Independent UK [Last accessed online on 2010 May 28].

9. National Agency For Food and Drug Administration and Control (NAFDAC). Pharmacovigilance News 2009;3:1-8.

10. Famuyiwa OO, Olorunshola DA, Derin A. Some family factors in sickle cell anaemia in Lagos, Nigeria. Nig Med Practitioner 1998;35:70-3.

11. Bankole OO, Denloye OO, Aderinokun GA. Attitude, beliefs and practices of some Nigerian nurses toward teething in infants. Odontostomatol Trop 2004;27:22-6.

12. Owais AI, Zawaideh F, Bataineh O. Challenging parent's myths regarding their children's teething. Int J Dent Hyg 2010;8:28-34.

13. Adimorah GN, Ubesie AC, Chinawa JM. Mothers' beliefs about infant teething in Enugu, South-east Nigeria: A cross sectional study. BMC Res Notes 2011;4:228.

14. Wake $\mathrm{M}$, Hesketh $\mathrm{K}$, Lucas J. Teething and tooth eruption in infants: A cohort study. Paediatrics 2000;106:1374-9.

15. Tighe M, Roe MF. Does a teething child need serious illness excluding? Arch Dis Child 2007;92:266-8.

16. Kermode-Scott B. US eases its restrictions on prescription drugs from Canada. BMJ 2006;333:824.

How to cite this article: Opeodu OI, Denloye OO. The use of medication as a preemptive strategy in teething children in a Nigerian community. Eur $\mathrm{J}$ Gen Dent 2014;3:109-12.

Source of Support: Nil, Conflict of Interest: None declared.

\section{Author Help: Online submission of the manuscripts}

Articles can be submitted online from http://www.journalonweb.com. For online submission, the articles should be prepared in two files (first page file and article file). Images should be submitted separately.

1) First Page File:

Prepare the title page, covering letter, acknowledgement etc. using a word processor program. All information related to your identity should be included here. Use text/rtf/doc/pdf files. Do not zip the files.

2) Article File:

The main text of the article, beginning with the Abstract to References (including tables) should be in this file. Do not include any information (such as acknowledgement, your names in page headers etc.) in this file. Use text/rtt/doc/pdf files. Do not zip the files. Limit the file size to $1 \mathrm{MB}$. Do not incorporate images in the file. If file size is large, graphs can be submitted separately as images, without their being incorporated in the article file. This will reduce the size of the file.

3) Images:

Submit good quality color images. Each image should be less than $4096 \mathrm{~kb}(4 \mathrm{MB})$ in size. The size of the image can be reduced by decreasing the actual height and width of the images (keep up to about 6 inches and up to about $1800 \times 1200$ pixels). JPEG is the most suitable file format. The image quality should be good enough to judge the scientific value of the image. For the purpose of printing, always retain a good quality, high resolution image. This high resolution image should be sent to the editorial office at the time of sending a revised article.

4) Legends:

Legends for the figures/images should be included at the end of the article file. 